\title{
Anticipating Market Effects of New Uses for Whey and Evaluating Returns to Research and Development
}

\author{
J. V. Balagtas, ${ }^{\star, 1}$ F. M. Hutchinson, $\dagger$ J. M. Krochta, $\neq^{2}$ and D. A. Sumner§ \\ *Department of Agricultural and Resource Economics, \\ University of California, Davis \\ †University of California Agricultural Issues Center \\ $\ddagger$ Department of Food Science and Technology, University of California, Davis \\ $\S$ University of California Agricultural Issues Center, Department of Agricultural and Resource Economics, \\ University of California, Davis, \\ and Giannini Foundation of Agricultural Economics
}

\section{ABSTRACT}

As U.S. dairy farms continue to become more productive, increasing demand is a key to improved economic prospects for the dairy industry. One way to expand demand for dairy products is to find new, economically viable uses for milk. Ex ante economic analysis of new uses for agricultural products anticipates the potential market effects of innovations, and provides a basis for evaluating investment in research and development and setting research priorities. This study evaluated potential economic effects of new applications of films and coatings made from whey protein. An economic simulation model was used to predict the likely effects of the innovations on dairy markets. Cost comparisons with existing technologies and interviews with industry officials were the basis for evaluating potential for commercial adoption of the innovations. The economic simulation model traces the projected increased demand for whey through the markets for dairy products and milk. The associated increased demand for milk could result in benefits to U.S. milk producers of $\$ 123.0$ million in present value terms, compared to a research cost of $\$ 4.9$ million, with the dairy industry, consumers, and taxpayers all contributing. Interpreting the cost of the research program as an investment on behalf of milk producers, the benefits to producers from development of new whey uses represent an annual rate of return between 28 and $33 \%$. These results are useful for evaluating further investment in the whey research program. The methods illustrated here are applicable to the evaluation of a wide range of research and promotion efforts.

Received October 17, 2002.

Accepted December 23, 2002.

Corresponding author: Daniel A Sumner; e-mail dasumner@ ucdavis.edu.

${ }^{1}$ Senior authorship is not assigned.

${ }^{2}$ Currently wih the New Zealand Ministry of Agriculture.
(Key words: economics, new uses, returns to research, research and development)

Abbreviation key: CDRF = California Dairy Research Foundation; IRR = internal rate of return; WPC80 = whey protein concentrate, $80 \%$ protein; WPI $=$ whey protein isolate.

\section{INTRODUCTION}

As the productivity of U.S. dairy farms increases, the prospects for enhanced returns to dairy producers depends on increased demand for dairy products. Although U.S. per capita consumption of cheese increased nearly four-fold in the last half of the 20th Century, per capita consumption of all dairy products fell by $17 \%$ over the same period, due in part to lower consumption of fluid milk products (USDA, 2000). With consumption of existing dairy commodities flat or falling, finding new uses for milk is a way of increasing demand for dairy products.

Agricultural R\&D efforts have influenced food and agricultural markets by lowering costs of production, reducing negative environmental consequences of agricultural activities, improving use of natural resources, and developing new uses for farm products. Ongoing research promises to affect tomorrow's markets. Ex ante economic analysis of research and development's potential market effects serves to anticipate market impacts of innovations, and also provides a basis for evaluating investment in research and setting research priorities (Alston et al., 1995; Alston and Pardey, 1996). This paper, joint work between food scientists and economists, demonstrates how economic analysis may provide ex ante evaluation of $R \& D$, drawing an example from the dairy industry.

At research institutions around the world, scientists are developing new uses for agricultural products. New uses promise added value to the agricultural product, higher product prices, and, ultimately, increased returns to the producer. For example, the development 
in the latter half of the 20th Century of high fructose corn syrup and ethanol produced from corn increased demand for corn (House et al., 1993; Lee, 1993; Lee et al., 1994). Technologies currently under development to produce diesel fuel and biodegradable plastics from corn are yet two more examples of potential new markets for agricultural products (Coble et al., 1992; Duffield and Shapouri, 1998). Costs of R\&D to create new uses may be distributed among various producer and consumer groups and, in the case of publicly funded research, taxpayers. Ex ante analysis of the potential economic effects of new uses can provide a preview of the distribution of benefits and costs among these same groups, and allow evaluation of each group's investment in $R \& D$.

Much recent research has examined and developed potential new uses of whey, particularly in the laboratory of one of the co-authors, John M. Krochta. With financial support from the dairy industry, consumers, and taxpayers, this research program is developing new applications for edible films and coatings made from whey protein, a by-product of cheese manufacture. In this paper, likely market effects resulting from commercial adoption of new whey protein products are analyzed and expected returns to investment in research are estimated.

Information from researchers and industry sources is built into an estimate of the potential adoption of the new technologies and a quantification of the associated increase in demand for whey. This information is incorporated into a simulation model of the U.S. dairy economy, yielding the expected changes in the prices and quantities of milk and dairy products due to adoption of the new technologies. Based on these simulations, expected benefits to dairy producers and returns to investment in research are estimated.

\section{A Brief Description of the Market for Whey}

In cheese manufacture, curds of protein and butterfat are extracted from milk to make cheese, leaving wheycomposed of water, lactose, minerals, and whey protein-as a by-product. In the recent past, commercial cheese manufacturers in the United States treated whey as sewage or returned whey to dairy farms to be fed to pigs or spread on fields. However, demand for whey's components and the development of whey processing techniques, as well as environmental and financial costs of whey disposal, have made it profitable to further process whey into its components, especially whey protein and lactose, for use as food ingredients. For example, whey protein is used in bakery products, infant formula, and sports bars.
The whey market has developed rapidly in the United States, but some cheese processors still do not have the technology to process whey. In particular, the cost of purchasing and installing whey-processing equipment has kept many smaller, older plants from processing and selling whey. As a result, approximately $30 \%$ of the total amount of whey from cheese manufacture is not sold. For the rest of the cheese industry, including most plants in the major cheese-producing regions such as the Upper Midwest and California, whey is actively marketed and supplies approximately $11 \%$ of the revenue from a modern cheese plant.

The ongoing research program at the University of California is developing new uses for whey protein in the form of films and coatings in both food and nonfood applications. For several of these technologies, progress in the laboratory indicates that commercial production will be possible by 2005 , and strong interest from potential industrial users suggests some likelihood of commercial adoption. Because the current technology for films and coatings does not use whey or any other dairy product, successful marketing or the new technologies will create new demand for whey, and new demand for milk.

The effects of increased whey demand on markets for milk and dairy products depend on the economic and technological relationships, and on the size of the new whey markets. Before discussing these economic consequences, details of both the whey research program and the potential markets for the new applications are described.

\section{New Uses for Whey Protein}

The new applications being investigated utilize the ability of processed whey protein, in the form of whey protein isolate (WPI) and whey protein concentrate $80 \%$ protein (WPC80), to form intact films and coatings on the surfaces of objects. The techniques used to form these films and coatings are described fully in the publications referenced below but can be described here briefly. For WPI films and coatings, a 10\% (by weight) solution of WPI is heated for $30 \mathrm{~min}$ to denature the proteins. This solution is then mixed with other ingredients, such as plasticizers, preservatives or lipids, in order to achieve desired characteristics. The solution is then cast onto plates to make films, or is coated onto products to make coatings. In the case of WPC80 films and coatings, the $\mathrm{pH}$ of the $10 \%$ WPC 80 solution must be adjusted with sodium hydroxide before denaturing the proteins. The solution is then treated in the same way as the WPI solution.

The research program is currently exploring seven different applications: 
(1) Grease-barrier coatings on paper and paperboard (Chan and Krochta, 2001a, 2001b): These coatings are used on packaging for products like fast food and pet food.

(2) Oxygen-barrier coatings on plastics (Hong and Krochta, 2003): Most plastics that are good moisture barriers are poor oxygen barriers. Thus, they are commonly coated to provide a good oxygen barrier.

(3) Gloss coatings on confectionery products (Lee et al., 2002; Lee et al., 2003): The most widely used glaze is shellac, also called confectioners glaze. Confectionery manufacturers are looking for an alternative glaze that will not have the tight EPA restrictions that accompany the use of shellac.

a. Gloss coatings on chocolate-panned confectionery is the specific application that has been most thoroughly investigated; gloss coatings on nonchocolate panned confectionery is expected to be a relatively simple extension of the chocolatepanned technology.

b. Gloss-coatings on other (non-panned) confectionery have not yet been investigated, but could potentially be viable.

(4) Oxygen-barrier coatings on foods (Lee and Krochta, 2002; Lee et al. 2002): Coating foods that are prone to oxidation (rancidity) will prolong their shelf life. Only edible films and coatings can be ingested with the food, thus eliminating the use of all synthetic plastics for these applications.

a. Oxygen-barrier coatings on snack peanuts. Nuts, such as peanuts, are prone to oxidation. A coating would prolong their shelf life.

b. Oxygen-barrier coatings on nuts used in confectionery bars. Like snack peanuts, nuts used in candy bars will oxidize, and limit the shelf life of the confectionery. Coating the nuts would improve the quality of the candy bar and extend the shelf life.

c. Oxygen-barrier coating on other foods. There are many other foods that could benefit from such coatings. However, only the applications on nuts have been investigated at this point.

The following applications are still in the very early stages of development:

(5) Moisture-barrier coatings on foods (Hutchinson, 2001): These can be used to prevent the movement of moisture from one component to another, preventing sogginess, unwanted chemical reactions and microbial growth to extend shelf life. There are currently no widely applicable products than can fulfill this need.

(6) Antimicrobial coatings on cheese: The coatings can be used on cheese to retain antimicrobial com- pounds on the surface. This will reduce the amount of antimicrobial compounds used, as it will no longer be necessary to compensate for the amount that moves into the cheese (Franssen, 2002).

(7) Extrusion and thermoforming films and containers: These are the techniques used to form films and containers in industry. Adapting these methods for use with whey protein will enable the mass manufacture of products such as water-soluble pouches and cups, for individual servings of various dry ingredients and foods.

\section{METHODS}

\section{Evaluating Potential Adoption and Increased Demand for Whey}

Currently, applications (1) through (4b) are at the point where formulations are available; all are still being improved. Nonetheless, for those applications, it has been possible to compare raw material costs of the whey protein application to that of the current technology (Table 1). We obtained pricing for the various ingredients by calling sales offices for potential suppliers. As there is no specific location for a manufacturing plant, we obtained freight on board (f.o.b.) prices at the supplier's location. Formulations used are the most recent available from the research group and may differ slightly from those in the referenced publications. Due to confidentiality issues, we cannot provide the formulations used in our raw material cost analyses.

Table 1 shows that the oxygen-barrier coatings on plastics (2), gloss coatings on panned confectionery (3a) and oxygen-barrier coatings on nuts for use in candy bars (4b) are likely to be adopted by industry at this time. With time for final refinements in the laboratory, commercial production for these applications is feasible by 2005. Snack nuts manufacturers have shown little interest in application (4a). However, the confectionery industry has shown strong interest in application (4b), indicating a high likelihood of adoption. The current competing technology for grease-barrier coatings on paper is still cheaper than the current whey protein formulation. As work continues to improve techniques and formulations, this application could become viable in the future.

The estimated effects on whey protein demand from the three applications considered likely to be adopted $(2,3$, and $4 \mathrm{~b})$ are shown in Table 2. The amount of additional whey protein demanded has been estimated assuming a low rate of adoption in which $25 \%$ of the relevant markets switch to a whey protein coating, a medium rate with $50 \%$, and a high rate with $75 \%$. The estimated increases in demand of whey protein are 2796 metric tons (MT) for a low rate of adoption, $5592 \mathrm{MT}$ 
Table 1. Comparison of raw material costs for the new whey protein applications and current technology.

\begin{tabular}{|c|c|c|c|}
\hline Application & $\begin{array}{l}\text { Current technology } \\
\text { application cost }\end{array}$ & $\begin{array}{l}\text { Whey protein } \\
\text { application cost }\end{array}$ & $\begin{array}{l}\text { Likely } \\
\text { adoption }\end{array}$ \\
\hline 1. Grease-barrier coatings on paper & $\begin{array}{l}\mathrm{PVOH}^{1} \text { coatings } \\
\$ 4.95 / 1000 \mathrm{ft}^{2,2}\end{array}$ & $\$ 6.72$ to $8.08 / 1000 \mathrm{ft}^{2,2}$ & No \\
\hline 2. Oxygen barrier coatings on plastics & $\begin{array}{l}\mathrm{EVOH}^{3} \text { coatings } \\
\$ 2.65 \text { to } 5.00 / \mathrm{b}^{4}\end{array}$ & $\$ 1.91$ to $2.36 / \mathrm{lb}^{4}$ & Yes \\
\hline $\begin{array}{l}\text { 3. Gloss coatings on chocolate } \\
\text { panned confectionery }\end{array}$ & $\begin{array}{l}\text { Shellac coating } \\
\$ 11.98 \text { to } 25.23 / 1000 \mathrm{lb}^{4} \\
\text { confectionery + potential } \\
\text { for environmental charges }\end{array}$ & $\begin{array}{l}\$ 21.15 \text { to } 28.66 / 1000 \\
\mathrm{lb}^{4} \text { confectionery }\end{array}$ & Yes \\
\hline $\begin{array}{l}\text { 4a. Oxygen barrier coatings on } \\
\text { snack peanuts }\end{array}$ & Novel technology & $\begin{array}{l}\text { Coating: } \$ 113 \text { to } 160 / \\
1000 \mathrm{lb}^{4} \text { nuts }\end{array}$ & $\mathrm{No}^{5}$ \\
\hline $\begin{array}{l}\text { 4b. Oxygen barrier coatings on } \\
\text { nuts in candy bars }\end{array}$ & Novel technology & $\begin{array}{l}\text { Coating: } \$ 113 \text { to } 160 / \\
1000 \mathrm{lb}^{4} \text { nuts }\end{array}$ & Yes $^{5}$ \\
\hline \multicolumn{4}{|l|}{$\begin{array}{l}{ }^{1} \mathrm{PVOH}=\text { Poly vinyl alcohol. } \\
{ }^{2} 1000 \text { square feet }\left(\mathrm{ft}^{2}\right)=92.9 \mathrm{~m}^{2} . \\
{ }^{3} \mathrm{EVOH}=\text { Ethlyene vinyl alcohol. } \\
{ }^{4} 1 \text { pound }(\mathrm{lb})=0.4536 \mathrm{~kg} .\end{array}$} \\
\hline
\end{tabular}

for medium adoption, and $8388 \mathrm{MT}$ for high adoption, with the largest increases from oxygen-barrier coatings on plastics and on nuts in confectionery bars. We calculate these values using U.S. cheese production data from the 2000 Dairy Product Summary (USDA 2001), and a curd yield of $12 \%$ for hard cheeses and $16 \%$ for soft cheese. The additional demand for whey protein is equivalent to between 1 and $4 \%$ of the estimated amount of whey protein available as a by-product of cheese manufacture in the United States.

\section{The Cost of R\&D Leading to New Uses of Whey Protein}

From 1990 through 2005, the projected date of first commercial adoption of whey coatings, the whey re- search project will have cost a present value of $\$ 4.9$ million, including actual outlays through 2002 and an estimate of whey research expenditures in 2003 through 2005, based on the recent annual outlays. (We adjust costs for inflation and use an $8 \%$ discount rate to bring annual costs to a 2002 present value in 2002 US dollars). This figure represents the cost of the entire research program, and includes the cost of developing new whey applications whose adoption and potential benefits we do not analyze here. Of the total research cost, $\$ 3.1$ million will have been paid by research grants from the U.S. dairy industry-the California Milk Advisory Board will have contributed $\$ 2.2$ million through the California Dairy Research Foundation (CDRF), which supports research that potentially benefits California's dairy industry, and Dairy Management, Inc.

Table 2. Estimated additional demand for whey protein by viable applications.

\begin{tabular}{lccc}
\hline & \multicolumn{3}{c}{ Rates of adoption $^{1}$} \\
\hline Application & Low & Medium & High \\
\hline & & Metric tons of protein & \\
\cline { 2 - 4 } & & & \\
(2) Oxygen-barrier coatings on plastics & & & \\
(3) Gloss coatings panned confectionery & 1314 & 837 & 3942 \\
(4b) Oxygen-barrier coatings on all nuts in confectionery & 1045 & 2089 & 1312 \\
Total additional whey protein demand & 2796 & 5592 & 3134 \\
As percentage of US total available whey protein & $1 \%$ & $3 \%$ & 8388 \\
\hline
\end{tabular}

\footnotetext{
${ }^{1}$ Low rate of adoption assumes $25 \%$ of the relevant markets adopt whey protein coatings, medium rate assumes $50 \%$, and high rate assumes $75 \%$.

${ }^{2}$ Assumes that whey protein coatings are suitable for only $25 \%$ of current market for coatings on plastics. Thus low adoption is $25 \%$ of $25 \%$ of the total market, medium adoption is $50 \%$ of $25 \%$ of the total market, and high adoption is $75 \%$ of $25 \%$ of the total market.
} 
(DMI) and other national sources will have contributed $\$ 0.7$ million. CDRF and DMI are each funded by marketing assessment. It is a standard economic result that such assessments affect market prices and quantities, and, thus, are paid by both producers and consumers (for example, see Chapter 9 of Pindyck and Rubinfeld, 2001). In this sense, milk producers and consumers each pay for a portion of the whey research project.

In addition to the dairy industry's contributions, the University of California will have contributed a present value of $\$ 0.13$ million in direct research grants, and also will have contributed approximately $\$ 1.8$ million toward the research program's indirect costs, including researcher and faculty salaries, lab and office space, and research dissemination efforts. To the extent that federal and California tax dollars support the University of California, federal and California taxpayers pay for the University's contribution to the whey research project.

This research program is developing a variety of new uses for whey protein, and is also generating more basic research that may have applications beyond the new uses currently being developed. The economic analysis discussed below considers adoption of only three of the new whey protein technologies developed by this research. To calculate returns to research from these three innovations, we must determine what portion of the total research cost $(\$ 4.9 \mathrm{M})$ is attributable to the three new uses. This issue is discussed below.

Regardless of how they are attributed to the various new whey applications, research costs have been distributed among milk producers, the dairy industry, consumers, and taxpayers. Potential benefits of this research are measured from the point of view of milk producers.

\section{The Economic Effects of Increased Whey Demand on U.S. Dairy Markets}

Successful marketing of new whey applications will result in increased demand for whey. The effects of this R\&D-induced shift in whey demand depend on the economic relationships that make up the markets for milk and dairy products.

Dairy product markets are complex. Raw milk is the primary input in processed dairy products, including several varieties of fluid milk; butter; nonfat dry milk; cheese; whey; ice cream, cultured products, etc. Thus, the price of raw milk is an important determinant of the cost of all dairy products, and an important determinant of the supply of these products. Consumer demand for each of the various dairy products, together with dairy product supply, determine prices in each of these markets, as well as the value of the milk input in each of these products.

Some dairy products are produced jointly from the different components of milk. For example, separating the cream portion of a given unit of milk to make butter leaves the nonfat portion available for producing nonfat fluid milk or nonfat dry milk. Similarly, cheese made from milk produces whey as a by-product. Except for these jointly produced outputs made from different components of raw milk, dairy products compete with each other for milk. For example, cheese and whey manufacturers can only increase production if they use more milk, and for a given quantity of milk supplied, this means less milk is available for use in butter and nonfat dry milk, fluid milk, or other dairy products. Such trade-offs play a major role in determining the implications for the dairy economy of increased whey demand.

Demand for raw milk for use in each of the processed products is derived from the demand for the processed products themselves, as well as the price and supply conditions of other inputs that are used along with raw milk. In order to satisfy increased demand for whey caused by the development of new uses for whey, more milk must be allocated to cheese and whey production, and again the trade-offs between milk's various uses come into play.

Milk prices serve as signals that, considering economic trade-offs, allocate milk to its various uses. In the U.S. and in California, a combination of market (supply and demand) and regulatory forces determine milk prices-see Sumner and Balagtas (2003a) for an overview of U.S. dairy policy, and Sumner and Balagtas (2003b) for discussion and analysis of the dairy provisions of the 2002 Farm Bill. While there are many elements of public policy in dairy, of immediate importance to the whey issue considered here is the milk pricing policies of milk marketing orders. Federal and California milk marketing orders set minimum prices for milk used in various products, and potentially affect the links between milk and dairy product markets. Marketing orders set milk prices based on formulae that take dairy product prices into account. The milk pricing formulae may not respond to changes in all dairy product markets, or may respond with some delay. We consider the effects of increased whey demand in the long term, in which milk and dairy product markets adjust so that milk prices reflect dairy product prices.

$R \& D$ that develops new uses for whey effectively increases demand for whey, with ripple effects on all other dairy product markets, as well as on the market for milk. The direction and magnitude of the resulting changes in key economic variables can be simulated by a class of models commonly used by economists to evaluate economic effects of research. Alston, et al. 
(1995) is the most widely cited exposition of these methods. The model used here starts with the markets for dairy products, including whey and cheese, and traces the effects of increased whey demand back to the market for milk and the effects on dairy farms. The economic and technological relationships that make up the markets for dairy products and milk in the United States are represented in the model as percentage changes, ratios of percentage changes, and shares. For example, demand for cheese is characterized in the model by the percentage decrease in the quantity of cheese demanded per 1 percentage-unit increase in cheese prices (i.e., the elasticity of demand for cheese). The role of milk in cheese manufacture is characterized in the model by the average cost share of milk in cheese production. The simulation model equations are specified in the appendix. Here, the focus is on the basic economic relationships that determine the market effects of increased demand for whey protein.

Taking into account these economic and technological relationships, the model quantifies the expected percentage changes in milk and dairy product prices and quantities due to an R\&D-induced increase in whey demand. Before turning to quantitative results, we briefly note the qualitative economic effects of an R\& D-induced increase in whey demand. Increased demand for whey results in a higher whey price, encouraging increased production of whey. Due to joint-production of whey and cheese, cheese production must also increase, putting downward pressure on cheese prices. As stated earlier, of the whey available in the U.S. from cheese production, approximately $30 \%$ is not processed or sold. This portion of unsold whey is mainly from smaller, older cheese plants that have not made the capital investment in whey-processing equipment. Thus, we expect most of the increased production of processed whey will come from increased cheese production from cheese plants with whey processing capacity. Higher whey prices will induce some plants to develop new whey processing capacity. The newly developed whey enterprise will make such a plant more profitable, and keeping it in business longer than otherwise, and thus increasing cheese production.

Increased demand for milk by cheese and whey manufacturers drives up the price of milk, encouraging greater milk production. At the same time, a higher milk price raises costs for manufacturers of butter, ice cream, and other dairy products, resulting in higher prices and reduced quantities for these products.

The net effect on milk producers is increased profits due to a higher price of milk, as illustrated in Figure 1. Increased demand for milk is represented by a shift in milk demand from $\mathrm{D}_{0}$ to $\mathrm{D}_{1}$, resulting in a higher milk price $\left(\mathrm{P}_{0}\right.$ to $\left.\mathrm{P}_{1}\right)$ and increased milk production $\left(\mathrm{Q}_{0}\right.$

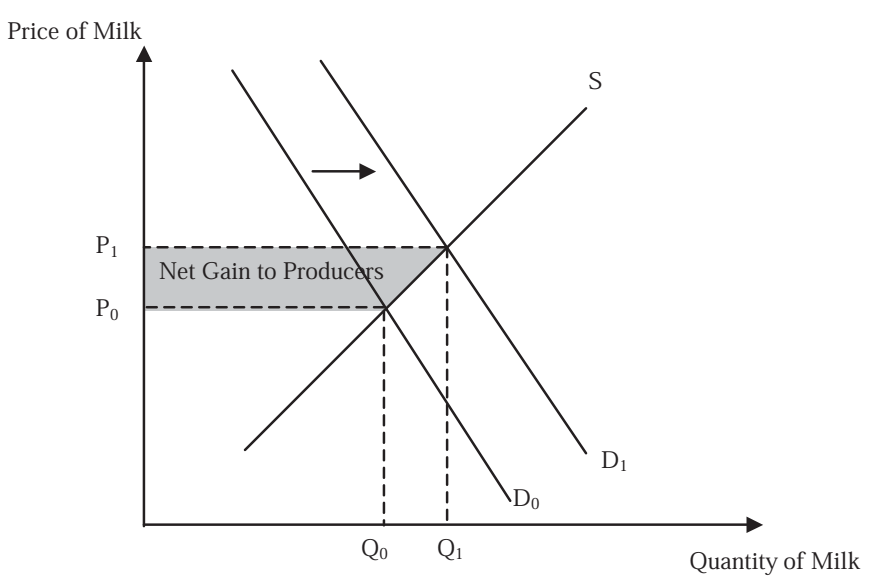

Figure 1. The market for raw milk in the U.S.

to $\mathrm{Q}_{1}$ ) along the milk supply curve, S. Increased returns to producers are represented in the figure by the shaded area to the left of the supply curve and between $P_{1}$ and $\mathrm{P}_{2}$. The magnitudes of the shift in milk demand, changes in the quantity and price of milk, and increased returns to producers depend on the economic and technological relationships that are embodied in the model's parameters. In the next section, choices of parameter values used in the model are documented, after which results are presented.

\section{Quantifying Supply, Demand, and Technological Relationships Used in the Model}

In this section, we discuss the quantitative economic and technological relationships needed to simulate the effects of increased whey demand. Where possible, values were assigned to the model's parameters based on published agricultural economics literature and public data. Where published estimates and data were lacking, knowledgeable industry sources and our own calculations were used. The magnitude, but not the direction, of results would be different under different parameter scenarios. Parameter values used for the scenarios reported in Table 3 are outlined below.

Demand for dairy products is characterized by elasticity of demand-the percentage change in quantity demanded for a 1 percentage-unit increase in price. We choose U.S. demand elasticities of -0.5 for cheese $(0.5$ percentage-unit decrease in quantity of cheese demanded in the U.S. for a 1 percentage-unit increase in cheese prices), and -0.5 for all dairy products other than whey and cheese based on estimates published in the agricultural economics literature (see Johnson et al., 1992). To our knowledge, no published estimated of the elasticity for demand for whey exists. We choose a value of -1.0 for the elasticity of demand for whey. 
Table 3. Parameters and Endogenous Variables of Equilibrium Displacement Model (equations (1)-(11)).

\begin{tabular}{|c|c|c|c|}
\hline \multirow[t]{3}{*}{ Symbol } & Definition & Values & Source \\
\hline & \multicolumn{3}{|l|}{$\longrightarrow$ Parameters } \\
\hline & $\begin{array}{l}\text { Increase in whey demand as a percentage } \\
\text { of current consumption }\end{array}$ & $1 \%, 3 \%, 4 \%$ & $\begin{array}{l}\text { authors' calculations } \\
\text { (see Table 2) }\end{array}$ \\
\hline$\eta_{\text {whey }}$ & Price elasticity of whey demand & -1.0 & \\
\hline$\eta_{\text {cheese }}$ & Price elasticity of cheese demand & -0.5 & ag. econ. literature \\
\hline$\eta_{\text {dairy }}$ & Price elasticity of other dairy product demand & -0.5 & ag. econ. literature \\
\hline$\alpha_{\text {cheese }}$ & Cost share of raw milk in cheese & 0.68 & USDA data \\
\hline$\alpha_{\text {dairy }}$ & Cost share of raw milk in other dairy products & 0.70 & authors' calculations \\
\hline$\gamma$ & $\begin{array}{l}\text { Ratio of whey revenue to cheese revenue } \\
\text { per unit of cheese output }\end{array}$ & 0.11 & USDA data \\
\hline$\varphi$ & Share of all raw milk used in cheese/whey & 0.37 & USDA data \\
\hline$\varepsilon_{\text {milk }}$ & Elasticity of raw milk supply & 0.5 & ag. econ. literature \\
\hline $\mathrm{Q}_{\text {whey }}$ & \multicolumn{3}{|l|}{ Quantity of whey } \\
\hline $\mathrm{Q}_{\text {cheese }}$ & \multicolumn{3}{|l|}{ Quantity of cheese } \\
\hline $\mathrm{Q}_{\text {dairy }}$ & \multicolumn{3}{|l|}{ Quantity of other dairy products } \\
\hline$Q_{\text {milk }}$ & \multicolumn{3}{|l|}{ Quantity of raw milk } \\
\hline$Q_{\text {milk,whey }}$ & \multicolumn{3}{|l|}{ Quantity of raw milk used in whey } \\
\hline $\mathrm{Q}_{\text {milk,cheese }}$ & \multicolumn{3}{|l|}{ Quantity of raw milk used in cheese } \\
\hline $\mathrm{Q}_{\text {milk,dairy }}$ & \multicolumn{3}{|l|}{ Quantity of raw milk used in other dairy products } \\
\hline $\mathrm{P}_{\text {whey }}$ & \multicolumn{3}{|l|}{ Wholesale price of whey } \\
\hline $\mathrm{P}_{\text {cheese }}$ & \multicolumn{3}{|l|}{ Wholesale price of cheese } \\
\hline $\mathrm{P}_{\text {dairy }}$ & \multicolumn{3}{|l|}{ Wholesale price of other dairy products } \\
\hline $\mathrm{P}_{\text {milk }}$ & \multicolumn{3}{|l|}{ Price of raw milk } \\
\hline
\end{tabular}

The responsiveness of the U.S. milk supply to changes in milk prices is captured by the elasticity of milk supply_the percentage change in quantity of milk supplied for a 1 percentage-unit increase in milk price. For a long-run time horizon that may apply to the spread of the market effects of new uses, we use a milk supply elasticity of 0.5 , which is well within the range of estimates found in the agricultural economics literature (Chavas and Klemme, 1986; Helmberger and Chen, 1994). In preliminary work, we used a supply elasticity of 1.0. As expected, qualitative results do not depend on choice of supply elasticity within a reasonable range, although percentage changes in prices and quantities of milk and dairy products vary slightly. For a milk supply elasticity of 1.0 producer benefits are somewhat smaller than those found with supply elasticity of 0.5 .

We choose other key parameter values based on 2001 dairy market data from the USDA. The cost share of milk in cheese/whey manufacture is $68 \%$. The average cost share of milk in the manufacture of all other dairy products is $70 \%$. The share of U.S. milk production allocated to cheese/whey production is $37 \%$. We also use USDA data to calculate the ratio of whey revenue to cheese revenue for a cheese plant. Based on prices of publicly traded dry whey and 40-pound (18.2 kg) block cheddar, and a ratio of 0.56 lbs of dry whey per pound of cheese, this ratio is $11 \%$.

The percentage increase in whey demand, $\theta$, was estimated based on the potential market size calculations discussed earlier and summarized in Table 2. For determining the expected impacts of new uses for whey, it is important to look at a variety of simulations because of lack of precision in knowledge about the market relationships. Based on the calculations in Table 2, we find that new whey applications could increase whey demand by between 1 and $4 \%$. We simulate effects of a low adoption rate (1\%), a medium adoption rate (3\%), and a high adoption rate (4\%).

\section{RESULTS AND DISCUSSION}

\section{Effects of a R\&D-induced Demand Shift for Whey}

The effects of low, medium, and high rates of adoption of the new whey technologies are modeled, and the implications for U.S. milk and dairy product prices and quantities, as well as the annual benefit to California producers are reported in Table 4. Low adoption increases whey prices by $0.96 \%$, medium adoption by $2.87 \%$, and high adoption by $3.82 \%$. Higher whey prices are accompanied by a reduction in cheese prices by $0.09 \%$ for low adoption, $0.27 \%$ for medium adoption, and $0.35 \%$ for high adoption. The fall in cheese prices is due to the joint production of whey and cheese; as cheese manufacturers receive more for whey, more milk is attracted to cheese processing; and with more cheese on the market, the price of cheese falls. However, because whey is a relatively small share (11\%) of cheese processors' revenue, the implied reduction in cheese 
Table 4. Simulation results: The effects of R\&D-induced increase in whey demand.

\begin{tabular}{|c|c|c|c|}
\hline Adoption rate of new whey applications & Low & Medium & High \\
\hline Percentage shift in U.S. whey demand & 1 & 3 & 4 \\
\hline \multicolumn{4}{|l|}{ Prices } \\
\hline Whey & 0.96 & 2.87 & 3.82 \\
\hline Cheese & -0.09 & -0.27 & -0.35 \\
\hline Other dairy & 0.02 & 0.05 & 0.06 \\
\hline Raw milk & 0.02 & 0.07 & 0.09 \\
\hline \multicolumn{4}{|l|}{ Quantities } \\
\hline Whey & 0.04 & 0.13 & 0.18 \\
\hline Cheese & 0.04 & 0.13 & 0.18 \\
\hline Other dairy & -0.01 & -0.02 & -0.03 \\
\hline Raw milk & 0.01 & 0.03 & 0.05 \\
\hline \multicolumn{4}{|l|}{ Revenue } \\
\hline Whey & 1.04 & 3.37 & 4.69 \\
\hline Cheese & -0.05 & -0.18 & -0.23 \\
\hline Cheese and whey ${ }^{1}$ & 0.07 & 0.22 & 0.31 \\
\hline Other dairy & 0.01 & 0.03 & 0.03 \\
\hline Raw milk & 0.03 & 0.10 & 0.14 \\
\hline US Milk Producer net gains & 5.0 & 17.4 & 22.4 \\
\hline
\end{tabular}

${ }^{1}$ Based on an average of $11 \%$ of cheese plant revenue from whey.

${ }^{2} 2002$ US dollars.

prices is relatively small. Cheese and whey quantities increase by $0.04 \%$ for low adoption, $0.13 \%$ for medium adoption, and $0.18 \%$ for high adoption.

Based on the percentage changes in prices and quantities, we calculate the percentage change in revenue for cheese and whey manufacturers, and milk producers. Whey revenue increases by $1.04 \%$ for low adoption, $3.37 \%$ for medium adoption, and $4.69 \%$ for high adoption. Similarly, cheese revenue falls by $0.05 \%$ for low adoption, $0.18 \%$ for medium adoption, and $0.23 \%$ for high adoption. Because whey accounts for approximately $11 \%$ of a cheese/whey plant's revenue, revenue for cheese/whey manufacturers increases by $0.07 \%$ for low adoption, $0.22 \%$ for medium adoption, and $0.31 \%$ for high adoption.

Raw milk prices rise by $0.02 \%$ for low adoption, $0.07 \%$ for medium adoption, and $0.09 \%$ for high adoption, due to increased demand from cheese/whey processors. Milk production rises by $0.01 \%$ for low adoption, $0.03 \%$ for medium adoption, and $0.05 \%$ for high adoption. Farm revenue rises by $0.03 \%$ for low adoption, $0.10 \%$ for medium adoption, and $0.14 \%$ for high adoption. As higher milk prices drive up manufacturers' costs, prices of dairy products other than cheese and whey rise by $0.02 \%$ for low adoption, $0.05 \%$ for medium adoption, and $0.06 \%$ for high adoption. Quantities of these products fall by $0.01 \%$ for low adoption, $0.02 \%$ for medium adoption, and $0.03 \%$ for high adoption.

The new uses for whey reduce the costs of manufacturing confectionery and plastic products. Thus, they benefit confectionery and plastic manufacturers as well as consumers of these products. Of particular interest here, however, are the effects on incomes of milk producers. Based on the market interactions and changes in prices and quantities described above, we may determine the implied benefits to producers.

Increased whey demand results in higher milk prices and increased milk production, making dairy farmers as a group better off. The last row of Table 4 reports a measure of the annual benefits of this whey research program to U.S. dairy farms as a group, calculated as the increase in total milk revenue net of marginal production costs (i.e., the change in producer surplus). Annual net gains to U.S. producers due to increased whey demand are $\$ 5.0$ million for low adoption, $\$ 17.4$ million for medium adoption, and $\$ 22.4$ million for high adoption (2002 dollars).

The expected net gains to dairy farms reported in Table 4 represent annual benefits. We calculate total benefits over the lifetime of adoption by projecting a pattern of adoption over time and discounting each year's benefits to a specified date. Although future adoption rates are uncertain, the strong interest shown thus far by confectionery and plastic manufacturers suggests that the whey-based coatings will be marketed successfully as indicated by the low, medium, and high adoption scenarios reported in Table 4.

We conservatively approximate total capitalized benefits by supposing that adoption starts at the low rate for the first 5 yr (2005 to 2009), continues at the medium rate for another $5 \mathrm{yr}$ (2010 to 2014), accelerates to the high rate for $10 \mathrm{yr}$ (2015 to 2024), then drops to the 
low rate for $10 \mathrm{yr}$ (2025 to 2034) before the whey products are replaced by newer technologies. Under this adoption pattern and the annual producer gains reported in Table 4, the 2002 present value of gains to U.S. producers is $\$ 123.0$ million (using an 8\% interest rate, as we did with the cost calculations).

Recall from the earlier section on costs that the whey research project will have cost a present value of $\$ 4.9$ million. The costs of the research project are attributable not only to the three whey applications considered here to be near commercial adoption, but also to those applications in earlier stages of research, and to those applications considered not likely to be adopted. Further, some of the research is more basic in nature and has potential for applications not discussed here or yet unforeseen. On the other hand, the benefits measured above are attributable only to the three whey applications considered near adoption. Thus, in order to calculate a return to the investment in research resulting in these three applications, we must know the portion of research costs attributable to these applications.

A conservative approach would be to attribute all costs to the three whey applications near adoption, which is equivalent to assuming that these are the only products of this research program, and ignoring potential benefits from any other applications. Considering benefits to producers alone and using a discount rate of $8 \%$, this conservative approach suggests a net present value of the investment in the whey research program of $\$ 118.1$ million ( $=\$ 123.0-\$ 4.9$ ). Alternatively, if half of the research costs are attributed to the three applications near adoption, the net present value of the investment in whey research is $\$ 120.5$ million $(=\$ 123.0$ $-2.5)$. These calculations represent the return to investment in this research program if we consider the investment decision as one made by dairy producers, even though consumers and taxpayers paid a portion of the investment cost, and consumers and others in the industry reaped some of the benefits.

An alternative way to consider the payoff from an investment in research is to calculate the internal rate of return (IRR) - the annual interest rate that would just make the net present value of the project $\$ 0$, so benefits equal costs in present value terms. If all research costs are attributed to the three applications near adoption, the IRR for returns to national producers on the investment in the whey research program is $28 \%$. The interpretation is that, from the dairy producers' perspective, the investment in whey research is preferable to any alternative investment yielding less than $28 \%$ annually. If we attribute half the research costs to the three applications near adoption, the IRR is $33 \%$.

Different time patterns of adoption yield different present value of net benefits. For likely rates of adop- tion, and given our estimates of annual benefits, expected net benefits are such that returns to investment in whey research, however measured, are positive and large. Further, our net present value measures may be conservative in that we attribute all costs of research to the three whey protein coatings likely to be adopted, and ignore the potential benefits from commercial adoption of whey products currently in early stages of development that also contribute to the costs of the overall research program on applications of whey protein.

Our measure of research benefits is also conservative in that we employ a narrow definition of benefits, counting only those benefits that accrue to milk producers. In Table 4, we do not include gains to producers or consumers of confectionery products and plastics. For this article, we treat the investment decision from the view of U.S. milk producers and consider only the benefit to these producers from a higher milk price. We do not include benefits to cheese and whey manufacturers, which also accrue to producer-members of dairy cooperatives that produce cheese and whey.

\section{CONCLUSION}

New uses for agricultural products promise added value to raw agricultural products, higher product prices, and, ultimately, higher returns to producers. Producers, consumers, and taxpayers finance the research efforts that create new uses. Ex ante economic analysis anticipates the market effects of new uses, and is the basis for evaluating investment in R\&D.

This paper illustrates the economic analysis of $R \&$ $\mathrm{D}$ in the context of new uses for whey protein being developed by researchers at the University of California. The magnitude and timing of the adoption of the new technologies is gleaned from the researchers and from industry sources. Based on this information, the likely increase in demand for whey is calculated. An economic simulation model then traces the effects of increased whey demand through the markets for dairy products and for milk, and quantifies the percentage changes in prices and quantities in these markets, as well as the annual net benefits to U.S. milk producers.

The research leading to the new whey uses, including uses not considered here, is projected to cost $\$ 4.9$ million. The U.S. dairy industry will have contributed $\$ 3.1$ million through check-offs, which are paid by both producers and consumers. Taxpayers also will have contributed through University of California's support of the research program. Our analysis considers the returns to the total investment in R\&D from the point of view of U.S. dairy producers.

For a conservative time-pattern of technology adoption, the present value of benefits to U.S. producers (net 
of the $\$ 4.9$ million invested in research) is between $\$ 120.5$ and $\$ 123.0$ million, depending on how much of the total cost of research is attributed to the technologies considered here. The implied IRR is between 28 and $33 \%$, suggesting that the investment in $R \& D$ is more profitable than any alternative investment yielding an annual return of less than 28 to $33 \%$. Thus, while total benefits to producers are small relative to dairy farm revenue-U.S. dairy farm cash receipts were $\$ 24.7$ billion in 2001-benefits are large relative to the cost of the investment. Considering that consumers and taxpayers paid a portion of the cost of the research program, producers' contribution to whey protein research appears to have been well spent.

\section{REFERENCES}

Alston, J. M., G. W. Norton, and P. G. Pardey. 1995. Science Under Scarcity: Principles and Practice for Agricultural Research Evaluation and Priority Setting. Cornell University Press, Ithaca, NY.

Alston, J. M., and P. G. Pardey. 1996. Making Science Pay: The Economics of Agricultural R\&D Policy. American Enterprise Institute Press, Washington, DC.

Balagtas, J. V., and D. A. Sumner. 2003. The effect of the Northeast Dairy Compact on producers and consumers, with implications of compact contagion. Rev. Ag. Econ. Accepted.

Chan, M. A., and J. M. Krochta. 2001a. Color and gloss of wheyprotein coated paperboard. Solutions (TAPPI). Oct. 2001, 58.

Chan, M. A., and J. M. Krochta. 2001b. Grease and oxygen barrier properties of whey-protein-isolate coated paperboard. Solutions (TAPPI). Oct. 2001, 57.

Chavas, J.-P., and R. M. Klemme. 1986. Aggregate milk supply response and investment behavior on U.S. dairy farms. Am. J. Agr. Econ. 68:55-66.

Coble, K., C. C. Chang, B. A. McCarl, and B. R. Eddleman. 1992. Assessing economic implications of new technology: the case of cornstarch-based biodegradable plastics. Rev. Ag. Econ. 14:33-43.

Duffield, J., and H. Shapouri. September 1998. Biodiesel development: new markets for conventional and genetically modified agricultural products. USDA, Economic Research Service, Agricultural Economics Report No. 770.

Franssen, L. R. 2002. Antimicrobial properties and diffusion modeling of preservative-containing whey protein films and coatings on Cheddar cheese. Ph.D. Thesis, University of California, Davis.
Helmberger, P., and Y. Chen. 1994. Economic Effects of U.S. Dairy Programs. J. Agr. Res. Econ. 19:225-238.

Hong, S.-I., and J. M. Krochta. 2003. Oxygen barrier properties of whey protein isolate coatings on polypropylene films. J. Food Sci. 68(1):224-228.

House, R., M. Peters, H. Baumes, and W. T. Disney. May 1993. Ethanol and agriculture: effects of increased production on crop and livestock sectors. USDA, Economic Research Service, Agricultural Economic Report, No. 667.

Hutchinson, F. M. 2001. Moisture barrier properties of whey proteinlipid composite films and coatings. M.S. Thesis, University of California, Davis.

Johnson, S. R., D. P. Stonehouse, and Z. A. Hassan. 1992. Market Demand for Dairy Products. Iowa State Press, Ames, IA.

Lee, H. 1993. Ethanol's evolving role in the U.S. automobile fuel market. Industrial Uses of Agricultural Materials Situation and Outlook Report. USDA, Economic Research Service.

Lee, H., J. Glauber, and D. A. Sumner. 1994. Increased industrial use of agricultural commodities: policy, trade, and ethanol. Contemporary Economic Policy XII:22-32.

Lee, S. Y., K. L. Dangaran, and J. M. Krochta. 2002. Gloss stability of whey-protein/plasticizer coating formulations on chocolate surface. J. Food Sci. 67:1121-1125.

Lee, S. Y., K. L. Dangaran, J.-X. Guinard, and J. M. Krochta. 2003. Consumer acceptance of whey-protein-coated versus shellaccoated chocolates. J. Food Sci. Accepted.

Lee, S. Y., and J. M. Krochta. 2002. Accelerated shelf life testing of whey-protein-coated peanuts analyzed by static headspace gas chromatography. J. Agric. Food Chem. 59(7):2022-2028.

Lee, S. Y., T. A. Trezza, J. X. Guinard, and J. M. Krochta. 2002. Whey-protein-coated peanuts assessed by sensory evaluation and static headspace gas chromatography. J. Food Sci. 67:1212-1218.

Pindyck, R. S., and D. L. Rubinfeld. 2001. Microeconomics 5th ed. Prentice Hall, New York, NY.

Sumner, D. A., and J. V. Balagtas. 2003a. An overview of U.S. dairy policy. Encyclopedia of Dairy Sciences. Hubert Roginski, John W. Fuquay, and Patrick F. Fox, eds., Academic Press.

Sumner, D. A., and J. V. Balagtas. 2003b. Implications for California of the dairy provision of the 2002 Farm Bill. The 2002 Farm Bill and California Agriculture. R. J. Sexton ed., Oakland: Univ. of CA, Div. of Agr. and Nat. Res. (Giannini Foundation research report no. 400).

USDA. 2000. Agriculture Fact Book 2000. Office of Communications, Washington, DC.

USDA. 2002. Milk Production, Disposition and Income, 2001 Summary. National Agricultural Statistics Service, Washington, DC.

USDA. 2001. Dairy Products 2000 Summary. National Agricultural Statistics Service, Washington, DC. 


\section{APPENDIX}

\section{An Equilibrium Displacement Model of the U.S. Dairy Sector}

Letting $\mathrm{E}$ denote percentage change (e.g., $\mathrm{EX}=\mathrm{d} \ln \mathrm{X}$ ), and defining all other notation in Table 3, our model of the U.S. dairy sector comprises the following eleven equations (these equations are derived in a brief that can be obtained from the authors):

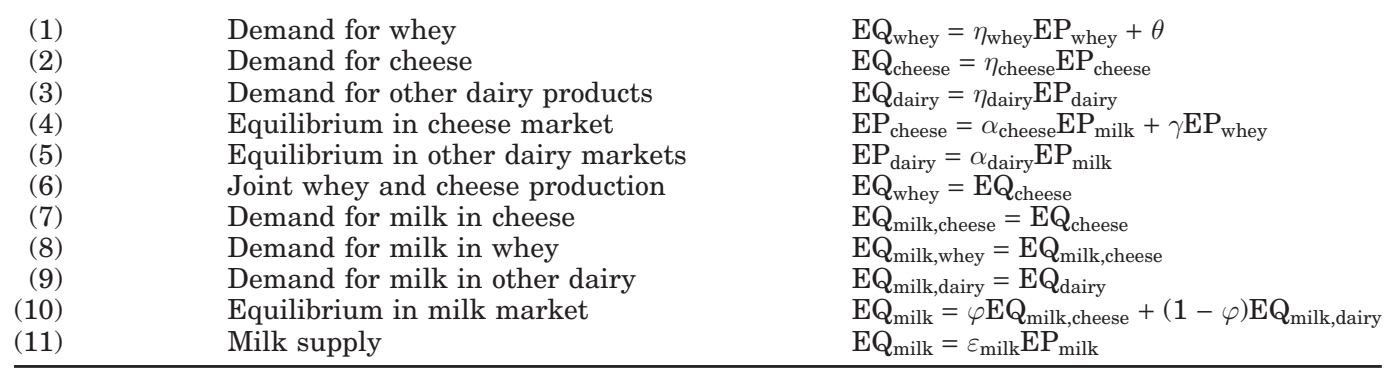

Equations (1) through (3) represent demand for U.S. whey, cheese, and an aggregate of all other dairy products. Equations (4) through (6) represent the equilibrium supply conditions for these products, assuming competitive markets for these products, and assuming that prices of inputs other than milk do not change due to increased demand for whey. Equation (7) is the demand for milk derived from the market for cheese, and equation (8) is the technological identity that says milk used to make cheese is also used to make whey. Equation (9) is the demand for milk derived from the market for dairy products other than whey and cheese. Equation (10) is the market clearing condition for raw milk. The U.S. supply of milk, equation (11), closes the model. Equations (1) through (11) can be solved to yield the equilibrium changes in the prices and quantities of milk and dairy products as functions of the economic and technological parameters, and of the R\&D-induced increase in whey demand, $\theta$. 